\title{
Model CNN LeNet dalam Rekognisi Angka Tahun pada Prasasti Peninggalan Kerajaan Majapahit
}

\author{
Tri Septianto, Endang Setyati ${ }^{*}$, Joan Santoso \\ Sekolah Tinggi Teknik Surabaya \\ Jl. Ngagel Jaya Tengah 73-77, Surabaya, Indonesia 60284
}

\begin{abstract}
Cara sitasi: T. Septianto, E. Setyati, and J. Santoso, "Model CNN LeNet dalam Rekognisi Angka Tahun pada Prasasti Peninggalan Kerajaan Majapahit," Jurnal Teknologi dan Sistem Komputer, vol. 6, no. 3, 2018. doi: 10.14710/jtsiskom.6.3.2018.106-109, [Online].
\end{abstract}

\begin{abstract}
The object of the inscription has a feature that is difficult to recognize because it is generally eroded and faded. This study analyzed the performance of CNN using LeNet model to recognize the object of year digit found on the relic inscriptions of Majapahit Kingdom. Object recognition with LeNet model had a maximum accuracy of $85.08 \%$ at 10 epoch in 6069 seconds. This LeNet's performance was better than the VGG as the comparison model with a maximum accuracy of $11.39 \%$ at 10 epoch in 40223 seconds.
\end{abstract}

Keywords - LeNet recognition performance; inscription digit recognition; $C N N$ performance comparison; $V G G$ recognition performance

Abstrak - Objek prasasti mempunyai fitur rekognisi yang sulit ditentukan karena umumnya sudah tererosi dan pudar. Penelitian ini menganalisis unjuk kerja CNN menggunakan model LeNet untuk mengenali objek angka tahun yang terdapat pada prasasti peninggalan kerajan Majapahit. Pengenalan objek dengan model Lenet mempunyai nilai akurasi yang setiap epoch mengalami peningkatan sampai mendapatkan nilai akurasi maksimal sebesar 85,08\% pada 10 epoch dalam waktu proses 6069 detik. Performansi LeNet ini lebih baik daripada model VGG sebagai pembanding dengan akurasi maksimal 11,39\% pada 10 epoch dalam waktu proses 40223 detik.

Kata Kunci - Kinerja rekognisi LeNet; pengenalan angka prasasti;perbandingan kerja CNN; kinerja rekognisi $V G G$

\section{Pendahuluan}

Dalam beberapa tahun ini, penelitian tentang rekognisi telah banyak dilakukan. Objek yang digunakan dalam penelitian rekognisi bervariasi, misalnya rel kereta [1], ekspresi wajah [2], plat nomor [3], tulisan tangan [4], dan tanda intonasi musik [5]. Metode yang digunakan pun beragam, misalnya deteksi

*) Penulis korespondensi (Endang Setyati)

Email: endang@stts.edu tepi [6], knn [7] dan svm [8]. Metode tersebut memerlukan sebuah fitur dari objek, misalnya tekstur, warna dan bentuk.

Namun di beberapa kasus, terdapat objek yang mempunyai fitur yang abstrak. Fitur abstrak biasanya ditemukan pada objek yang telah mengalami erosi dan pudar. Objek tersebut umumnya berusia sangat tua, misalnya prasasti. Convolutional neural network (CNN) dapat digunakan untuk mengenali fitur yang abstrak [9], [10]. Teknik CNN ini telah digunakan untuk rekognisi objek karakter tulisan tangan Mayalam [11], rekognisi karakter tulisan Persia [12], rekognisi karakter tulisan angka Bangla [13], rekognisi karakter tulisan Jawa [14], rekognisi karakter tulisan Cina [15] dan rekognisi karakter tulisan tangan Bengali [16]. Secara khusus, Shokoohi [12] menggunakan algoritma k-SVD sebagai ekstraksi fitur non-linear dan CNN.

Tiap karakter tulisan yang perlu dikenali tersebut di atas mempunyai fitur yang unik. Selain itu, metode CNN tersebut membutuhkan arsitektur model yang juga beragam. Penelitian ini bertujuan mengaplikasikan model LeNet dalam CNN untuk rekognisi angka pada prasasti angka tahun peninggalan kerajaan Majapahit. Performansi LeNet ini dan waktu prosesnya dianalisis dan dibandingkan dengan model VGG menggunakan metode ADADELTA [17].

\section{Metode Penelitian}

Dataset yang digunakan dalam penelitian ini merupakan citra angka pada prasasti angka tahun peninggalan Kerajaan Majapahit, seperti sampel dalam Gambar 1. Dataset mempunyai dimensi 224×224 pixel. Dataset terdiri dari 10 kelas, yaitu kelas $0,1,2,3,4,5,6,7,8$ dan 9. Dataset mempunyai 100 gambar pada masingmasing kelas sehingga total data yang dipakai yaitu 1000 citra. Dataset ini yang digunakan dalam penelitian ini tersedia dalam Lampiran.

Arsitektur model yang digunakan untuk rekognisi karakter dari citra dataset adalah LeNet. Diagram blok model LeNet ini ditunjukkan dalam Gambar 2. Lenet digunakan menggunakan ukuran masukan sebesar $32 \times 32 \times 1$ dengan menggunakan filter $5 \times 5,1$ strides dan 0 pool. Dari ukuran matriks $32 \times 32$ dilakukan pembentukan matriks konvolusi menggunakan Persamaan 1 dan Persamaan 2. Matriks konvolusi 


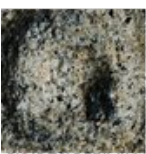

0

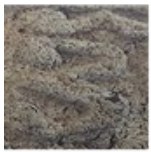

5

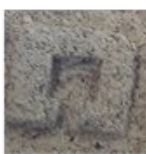

1

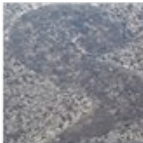

6

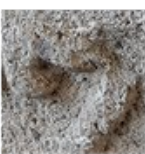

2

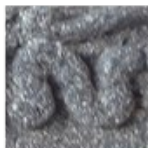

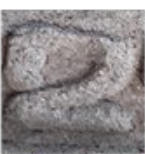

3

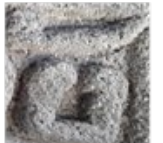

8

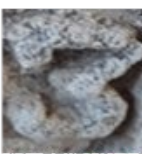

4

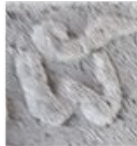

9
Gambar 1. Contoh citra angka pada prasasti

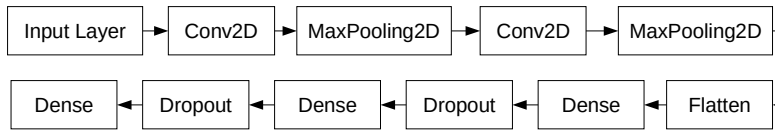

Gambar 2. Diagram blok LeNet

\begin{tabular}{|l|l|l|l|}
\hline 2 & 4 & 5 & 8 \\
\hline 4 & 6 & 7 & 6 \\
\hline 2 & 2 & 9 & 6 \\
\hline 6 & 8 & 7 & 6 \\
\hline
\end{tabular}$\rightarrow$\begin{tabular}{|l|l|}
\hline 6 & 8 \\
\hline 8 & 9 \\
\hline
\end{tabular}

Gambar 3. Visualisasi maxpooling2D

mempunyai ukuran $28 \times 28$. Proses diskretisasi dilakukan berdasarkan sampel menggunakan maxpooling $2 D$ menggunakan filter $2 \times 2$ seperti ditunjukkan dalam Gambar 2.

Simulasi model LeNet dan analisisnya dilakukan dengan menggunakan ADADELTA [17]. Metode ini menggunakan penalaan dinamik pada learning rate dan stabil pada informasi gradien yang berderau dan mampu mendukung arsitektur yang berbeda dan variasi parameter sebuah arsitektur model. Uji performansi LeNet dibandingkan dengan model VGG [18] dengan masukan yang sama. VGG terdiri dari 16 lapisan konvolusional dengan filter konvolusi $3 \times 3$. Analisis data dilakukan dengan membandingkan hasil akurasi dan waktu proses dari 2 model dalam pelatihan, yaitu LeNet dan VGG (Gambar 4).

\section{Hasil dan Pembahasan}

Pengujian model dilakukan dengan cara menjadikan dataset gambar angka pada prasasti angka tahun sebagai masukan ke dalam arsitektur model Lenet dan VGG. Parameter masukan pada arsitektur model menggunakan 10 epoch, ukuran batch 32, sampel pelatihan 1000 dan sampel validasi 1000 . Dalam penelitian ini digunakan 1000 citra pada dataset untuk proses pelatihan dan 1000 citra pada dataset untuk validasi. Validasi digunakan untuk melihat nilai akurasi tiap epoch. Setelah proses pengenalan oleh model selesai, hasil dari pelatihan disimpan, yaitu berupa waktu proses dan nilai akurasi per epoch. Suatu arsitektur model dikatakan baik jika nilai akurasi per-epoch mengalami peningkatan. Karena metode CNN bergantung pada penentuan arsitektur

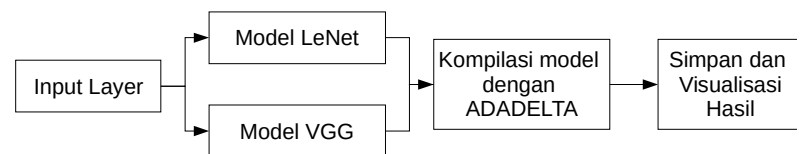

Gambar 4. Alur kompilasi dan pengujian model

Tabel 1. Hasil pengujian dengan LeNet

\begin{tabular}{ccc}
\hline Epoch & Waktu (detik) & Akurasi \\
\hline 1 & 669 & 0,1381 \\
2 & 625 & 0,2460 \\
3 & 644 & 0,3690 \\
4 & 601 & 0,5192 \\
5 & 605 & 0,6441 \\
6 & 598 & 0,7208 \\
7 & 591 & 0,7550 \\
8 & 590 & 0,7803 \\
9 & 587 & 0,8185 \\
10 & 559 & 0,8508 \\
\hline Jumlah & 6069 & \\
\hline
\end{tabular}

Tabel 2. Hasil pengujian dengan VGG

\begin{tabular}{ccc}
\hline Epoch & Waktu (detik) & Akurasi \\
\hline 1 & 4086 & 0,1139 \\
2 & 4053 & 0,1008 \\
3 & 4021 & 0,1129 \\
4 & 3978 & 0,1088 \\
5 & 4052 & 0,0998 \\
6 & 4010 & 0,1078 \\
7 & 3978 & 0,0877 \\
8 & 4050 & 0,1018 \\
9 & 3984 & 0,0938 \\
10 & 4011 & 0,1099 \\
\hline Jumlah & 40223 & \\
\hline
\end{tabular}

model, jika arsitektur model tersebut kurang baik, maka hasil nilai akurasi $\mathrm{CNN}$ tersebut juga kurang baik.

Hasil pengujian model LeNet ditunjukkan dalam Tabel 1. Model LeNet menjalankan 10 epoch proses pelatihan dalam waktu 6069 detik dan mempunyai akurasi yang semakin meningkat setiap epoch dengan akurasi terbaik sebesar 0,8508 atau 85,08 \%. Model ini mempunyai akurasi yang lebih rendah dibandingkan dalam [14] dengan akurasi 94,57\% untuk mengenali 20 kelas karakter huruf bahasa Jawa menggunakan model diskriminatif. Akurasi LeNet dengan 10 epoch ini juga lebih rendah daripada dalam [15], [16]. Akurasi LeNet ini dapat meningkat saat dilakukan lebih banyak pelatihan, namun hal ini akan memerlukan waktu proses pelatihan lebih lama.

Sebagai pembanding, dataset citra angka pada prasasti angka tahun juga diuji coba dengan menggunakan arsitektur model VGG. Hasil pengujian model VGG ditunjukkan dalam Tabel 2. Parameter masukan yang digunakan pada arsitektur model VGG juga sama dengan parameter masukan arsitektur LeNet, yaitu menggunakan 10 epoch, ukuran batch 32, sampel pelatihan 1000 dan sampel validasi 1000. Model VGG 


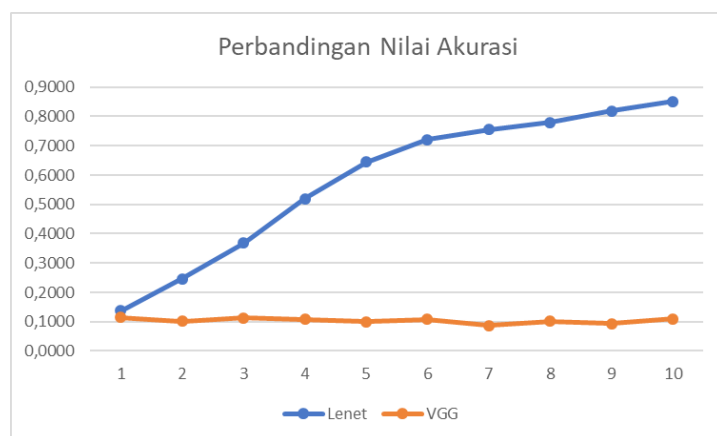

Gambar 4. Perbandingan nilai akurasi LeNet dan pembanding VGG

menjalankan 10 epoch proses pelatihan dalam waktu 40223 detik dan mendapatkan akurasi yang tidak semakin meningkat dengan maksimal sebesar 0,1139 atau $11,39 \%$.

Peningkatan nilai akurasi model LeNet dan perbandingannya dengan model VGG, seperti dalam Gambar 4, menunjukkan bahwa model LeNet untuk CNN ini dapat digunakan dalam rekognisi angka tahun prasasti yang fiturnya abstrak seperti dinyatakan dalam [9], [10]. LeNet ini dapat mengenali angka dari 1000 sampel citra prasasti dengan akurasi yang baik, seperti halnya model-model dalam [11]-[16], yang digunakan untuk rekognisi objek-objek abstrak yang lain. Waktu proses pelatihan LeNet juga lebih singkat dibandingkan model VGG yang dijadikan pembanding sehingga untuk mencapai akurasi seperti [14]-[16] dapat dilakukan dengan menjalankan proses pelatihan lebih banyak.

\section{KESIMPULAN}

Arsitektur model LeNet dapat digunakan dalam rekognisi angka pada prasasti angka tahun peninggalan kerajaan Majapahit dengan nilai akurasi yang semakin meningkat dalam setiap epoch selama pelatihan dan membutuhkan waktu 6069 detik untuk 10 epoch dengan akurasi maksimal 85,08\%.

\section{LAMPIRAN}

Artikel disertai lampiran terpisah yang berisi dataset penelitian yang dapat diunduh dari tautan di laman web artikel ini (doi: 10.14710/jtsiskom.6.3.2018.107-110).

\section{Daftar Pustaka}

[1] L. Shang, Q. Yang, J. Wang, S. Li, and W. Lei, "Detection of Rail Surface Defects Based on CNN Image Recognition and Classification," in 2018 20th International Conference on Advanced Communication Technology (ICACT), Chuncheonsi Gangwon-do, Korea, Feb. 2018, pp. 45-51.

[2] X. Zhao, X. Shi, and S. Zhang, "Facial Expression Recognition via Deep Learning," IETE Technical Review, vol. 32, no. 5, pp. 347-355, 2015.

[3] Y. Yang, D. Li, and Z. Duan, "Chinese Vehicle License Plate Recognition using Kernel-based
Extreme Learning Machine with Deep Convolutional Features," IET Intelligent Transport Systems, vol. 12, no. 3, pp. 213-219, 2017.

[4] H. D. Nguyen and M. Nakagawa, "Deep Neural Networks for Online Handwritten Mathematical Characters," in 18th Meeting on Image Recognition and Understanding, 2015, pp. 1-2.

[5] S. Lee, S. J. Son, J. Oh, and N. Kwak, "Handwritten Music Symbol Classification Using Deep Convolutional Neural Networks," in 2016 International Conference on Information Science and Security, Pattaya, Thailand, Dec. 2016, pp. 1-5.

[6] S. Nagaraj, B. Muthiyan, S. Ravi, V. Menezes, K. Kapoor, and H. Jeon, "Edge-based Street Object Detection," in 2017 IEEE SmartWorld, Ubiquitous Intelligence \& Computing, Advanced \& Trusted Computed, Scalable Computing \& Communications, Cloud \& Big Data Computing, Internet of People and Smart City Innovation (SmartWorld/SCALCOM/UIC/ATC/CBDCom/IOP/ SCI), Jun. 2017, pp. 1-4.

[7] A. R. F. Quiros et al., "A kNN-based Approach for the Machine Vision of Character Recognition of License Plate Numbers," in 2017 IEEE Regional 10 Conference (TENCON 2017), Nov. 2017, pp. 1081-1086.

[8] D. Singh, M. A. Khan, A. Bansal, and N. Bansal, "An Application of SVM in Character Recognition with Chain Code," in 2015 Communication, Control, and Intelligent Systems (CCIS), Mathura, India, Nov. 2015, pp. 167-171.

[9] M. Y. W. Teow, "Understanding Convolutional Neural Networks Using A Minimal Model for Handwritten Digit Recognition," in 2017 IEEE 2nd International Conference on Automatic Control and Intelligent Systems (I2CACIS), Kota Kinibalu, Malaysia, Oct. 2017, pp. 167-172.

[10] S. Albawi, T. A. Mohammed, and S. Al-Zawi, "Understanding of a Convolutional Neural Network," in 2017 International Conference on Engineering and Technology (ICET), Antalya, Turkey, Aug. 2017, pp. 1-6.

[11]P. P. Nair, A. James, and C. Saranavan, "Malayalam Handwritten Character Recognition using Convolutional Neural Network," in 2017 International Conference on Inventive Communication and Computational Technologise (ICICCT), Coimbatore, India, Mar. 2017, pp. 278 281.

[12]Z. Shokoohi, A. M. Hormat, F. Mahmoudi, and H. Badalabadi, "Persian Handwritten Numeral Recognition using Complex Neural Network and Non-linear Feature Extraction," in 2013 1st Iranian Conference on Pattern Recognition and Image Analysis (PRIA). Birjand, Iran, Mar. 2013.

[13] M. A. H. Akhand, M. M. Rahman, P. C. Shill, S. Islam, and M. M. H. Rahman, "Bangla Handwritten Numeral Recognition using Convolutional Neural Network," in 2015 International Conference on Electrical Engineering and Information 
Communication Technology (ICEEICT), Dhaka, Bangladesh, May 2015, pp. 1-5.

[14] M. A. Wibowo, M. Soleh, W. Pradani, A. N. Hidayanto, and A. M. Arymurthy, "Handwritten Javanese Character Recognition using Descriminative Deep Learning Technique," in 2017 2nd International Conference on Information Technology, Information Systems and Electrical Engineering (ICITISEE), Yogyakarta, Indonesia, Nov. 2017, pp. 324-329.

[15] M. He, S. Zhang, H. Mao, and L. Jin, "Recognition Confidence Analysis of Handwritten Chinese Character with CNN," in 2015 13th International Conference on Document Analysis and Recognition
(ICDAR), 2015, pp. 61-65.

[16] T. Datta, B. Purkaystha, and M. S. Islam, "Bengali Handwritten Character Recognition Using Deep Convolutional Neural Network," in 2017 20th International Conference on Computer and Information Technology (ICCIT), Dhaka, Bangladesh, Dec. 2017, pp. 22-24.

[17] M. D. Zeiler, "ADADELTA: An Adaptive Learning Rate Method," arXiv: 1212.5701 [cs.LG], Dec. 2012.

[18] K. Simonyan, and A. Zisserman, "Very Deep Convolutional Networks for Large-Scale Image Recognition," arXiv: 1409.1556 [cs.CV], Sept. 2014. 